\title{
Aspek-Aspek Psikologis pada Prosesi Rambu Solo' (Tinjauan Teori Religiusitas)
}

\author{
Reyvences Asgrenil Lusi \\ Program Magister Psikologi Sains Fakultas Psikologi Universitas Surabaya \\ lusireyven@gmail.com \\ Listyo Yuwanto \\ Program Magister Psikologi Sains Fakultas Psikologi Universitas Surabaya \\ miauw_99@yahoo.com
}

\begin{abstract}
This literature review aims to review the psychological aspects, especially the religiosity aspects contained in the implementation of the Rambu Solo' procession in the Toraja tribes. Rambu Solo' is the procession of delivering or burying the dead by their families to the spiritual realm or puya (heaven). In its implementation, there are adjustments as well as shifts in the implementation of the Rambu Solo' procession "which was carried out in the past compared to the implementation of the Rambu Solo' today. Rambu Solo' is a concept of religiosity that exists today, especially in the Toraja tribes because this procession is carried out not only based on ancestral beliefs but also based on religious values that have entered and developed in the Toraja region.
\end{abstract}

Keywords: procession; rambu solo'; religiosity

\begin{abstract}
Abstrak
Kajian literatur ini bertujuan untuk meninjau aspek-aspek psikologis khususnya aspek religiusitas yang terdapat dalam pelaksanaan prosesi rambu solo' pada masyarakat suku Toraja. Rambu solo' adalah prosesi pengantaran atau penguburan jenazah orang yang meninggal oleh keluarganya menuju alam roh atau puya (surga). Dalam pelaksanaannya, terdapat penyesuaian dan juga pergeseran dalam pelaksanaan prosesi rambu solo' yang dilaksanakan pada jaman dulu dibandingkan dengan pelaksanaan rambu solo' pada masa kini. Rambu solo' adalah sebuah konsep religiusitas yang ada pada kehidupan saat ini khususnya pada masyarakat suku Toraja karena prosesi ini dilaksanakan tidak hanya didasarkan pada kepercayaan leluhur namun juga berdasarkan kepada nilai-nilai agama yang telah masuk dan berkembang di wilayah Toraja.
\end{abstract}

Kata kunci: prosesi, rambu solo’', religiusitas 


\section{Pendahuluan}

Kematian adalah sebuah kenyataan dalam kehidupan kita yang tidak dapat ditolak dan dihindari. Peristiwa kematian dapat dilihat dari berhentinya atau tidak berfungsinya lagi organ-organ vital dalam individu yang mengalami kematian. Dengan kata lain, dengan datangnya kematian, maka akan berakhir pula kehidupan pada orang yang mengalaminya di dunia. Kematian dapat dialami oleh siapapun tanpa mengenal usia, jenis kelamin, status sosial dan tidak ada satupun yang mengetahui kapan dirinya akan mengalami kematian tersebut.

Dalam menghadapi kematian tentunya tidak terlepas dari budaya. Kebudayaan merupakan sistem sosial yang berfungsi sebagai acuan bagi masyarakat dalam menghadapi fenomena yang ada, dalam hal ini kematian. Indonesia sebagai Negara dengan aneka ragam kebudayaan tentunya akan terlihat pula beragam cara atau prosesi dalam menghadapi kematian. Bentuk kebudayaan ini merupakan warisan atau kebiasaan yang sudah dilaksanakan oleh generasi sebelumnya secara turun-temurun sampai dengan generasi kita pada saat ini.

Salah satu daerah yang memiliki budaya tersendiri prosesi dalam menghadapi kematian di Indonesia adalah Toraja. Masyarakat suku Toraja dalam kesehariannya sampai dengan saat ini masih menjalankan tradisi rambu solo'. Tradisi ini adalah sebuah upacara atau prosesi yang dilakukan oleh masyarakat suku Toraja ketika mengalami peristiwa kematian. Upacara rambu solo' bertujuan untuk menghormati dan mengantarkan arwah orang yang meninggal dunia menuju alam roh, bersama para leluhur mereka yang bertempat di puya (surga). Upacara ini sebagai penyempurnaan, karena orang yang baru dianggap benarbenar wafat setelah seluruh prosesi upacara ini digenapi. Jika belum, maka orang yang wafat itu hanya dianggap sebagai orang yang sakit atau lemah, sehingga ia tetap diperlakukan seperti halnya ketika masih hidup, yaitu dibaringkan di tempat tidur dan diberi makanan dan minuman, bahkan diajak berbicara. (Wahyuningsih, 2018). Perlakuan ini dilakukan oleh anggota keluarga terhadap anggota keluarganya yang meninggal dengan berpedoman atau mengikuti perlakuan yang sama yang sudah diterapkan oleh generasi sebelumnya pada masyarakat suku Toraja. 
Dari hasil wawancara yang dilakukan penulis kepada salah satu orang Suku Toraja diketahui bahwa tradisi ini masih terus berlangsung sampai sekarang, hanya saja dalam pelaksanaannya yang lebih menyesuaikan dengan kondisi saat ini. Misalnya dalam bentuk sumbangan, anggota keluarga yang tidak tinggal di wilayah toraja biasanya memberi sumbangan dalam bentuk uang tunai.

\footnotetext{
"Sumbangan itu dikasih dalam bentuk hewan seperti ayam, kerbau, atau babi. Tapi ada juga yang menyumbang dalam bentuk amplop (uang) yang biasa dikasih oleh keluarga jauh. Dikasih amplop saja karena pikirnya nanti ketika balas budi lebih berat. Yang kedua karena jarak, jarak yang jauh itu lebih ringan kalau kasih amplop saja, bisa juga kalau jauh kasih kerbau, tapi harus titip jadi merepotkan orang lagi”.
}

Rambu solo' menjadi fenomena unik dan menarik dikarenakan proses pelaksanaannya. Bahkan, dalam pelaksanaan prosesi ini tak jarang diikuti juga oleh para wisatawan baik itu wisatawan lokal maupun wisatawan mancanegara. Secara etimologis, kata rambu Solo’ berasal dari Bahasa toraja yang mana terdiri dari dua kata, yaitu rambu (asap atau sinar) dan solo (turun). Karena itu, rambu Solo' dapat diartikan sebagai upacara yang dilaksanakan pada waktu sinar matahari mulai turun (matahari terbenam). Pelaksanaan prosesi ini biasanya dilakukan selama bebrapa hari bahkan bisa berminggu-minggu. Ketika ada anggota keluarga yang meninggal dalam masyarakat suku Toraja, rambu solo' biasanya tidak langsung dilaksanakan akan tetapi dilaksanakan setelah berapa hari, bulan, bahkan bertahun-tahun setelah peristiwa kematian yang dialami oleh anggota keluarga dalam suku Toraja. Hal ini dikarenakan pelaksanaan rambu solo' yang cukup kompleks karena terdapat beberapa tahapan dalam pelaksanannya. Terdapat 7 tahapan di dalam pelaksanaan rambu solo' yaitu, ma' palele (memindahkan jenazah ke lokasi kegiatan), ma’ pasilaga tedong (adu kerbau), ma' parokko alang (memindahkan jenazah dari tongkonan ke lumbung), ma' pasonglo' (pemindahan jenazah ke lakkian atau tempat persemayaman terakhir sebelum dikebumikan), mantarima tamu (menerima tamu) mantunu (pemotongan kerbau), dan ma' kaburu (acara penguburan). Selain itu juga, sebelum pelaksanaannya harus mengumpulkan seluruh anggota keluarga dari orang yang meninggal tersebut sebelum melaksanakannya. 
Dalam prosesi rambu solo’ juga mengharuskan anggota keluarga dari orang yang meninggal untuk mempersembahkan hewan kurban berupa kerbau dan babi. Adapun jumlahnya menyesuaikan dengan kelas sosial dari keluarga yang meninggal tersebut. Kerbau atau tedong dan babi yang ada kemudian disembelih dan dagingnya dimasak untuk kemudian dimakan bersama baik itu oleh keluarga maupun juga masyarakat di sekitar.

Beberapa penelitian sebelumnya terkait rambu solo' hanya sebatatas melakukan kajian sosial-budaya dalam prosesi ini seperti penelitian yang dilalukan oleh Guntara, dkk (2016). Penelitian lain yang dilakukan pun hanya mengkaji simbol-simbol yang digunakan dalam pelaksanaan prosesi rambu solo' seperti tedong sebagai syarat dalam pelaksanaan prosesi rambu solo' (Mangopang, dkk; 2018), ataupun bentuk Komunikasi Fatis yang diterapkan dalam prosesi rambu solo' (Mangera, dkk; 2018). Adapun hasil kajian seacara psikologis mengenai pelaksanaan rambu solo' oleh masyarakat suku Toraja hanya melihat dari sisi dampak bagi pelaku pelaksanaan prosesi ini (Marwing, 2011).

Prosesi pelaksanaan rambu solo' pada jaman sekarang ini mengalami sedikit penyesuaian. Penelitian yang dilakukan oleh Hasbi, Sukimi, dan Mutalib (2016) menemukan hasil bahwa terdapat perbedaan dalam pelaksanaan prosesi rambu solo' yang dilaksanakan pada jaman dulu dibanding dengan pelaksanaan padajaman kini. Penelitian yang dilakukan di wilayah Makale Utara, Tana Toraja mendapati hasil penelitian yang sebagai berikut :

Tabel 1. Perbedaan Rambu Solo’' Dulu dan Kini

\begin{tabular}{|c|c|c|c|}
\hline No & $\begin{array}{c}\text { Aspek } \\
\text { Perbedaan } \\
\end{array}$ & Rambu Solo' Dulu & Rambu Solo' Kini \\
\hline 1 & $\begin{array}{l}\text { Dasar } \\
\text { kepercayaan }\end{array}$ & Aluk Todolo. & Agama (Kristen) \\
\hline 2 & Makna upacara & $\begin{array}{l}\text { - Keselamatan arwah di langit. } \\
\text { - Memberi berkat untuk } \\
\text { keturunannya. }\end{array}$ & $\begin{array}{l}\text { - Bentuk kasih sayang } \\
\text { - Sebagai penghormatan } \\
\text { - Sebagai perekat sosial } \\
\end{array}$ \\
\hline 3 & Motif & Budaya & $\begin{array}{l}\text { - Budaya } \\
\text { - Status sosial } \\
\text { - Ekonomi } \\
\end{array}$ \\
\hline 4 & $\begin{array}{l}\text { Sikap ke aluk } \\
\text { dan adat }\end{array}$ & Diikuti seluruhnya & $\begin{array}{l}\text { - Sikap tidak kritis } \\
\text { - Sikap kritis yang mau } \\
\text { memisahkan aluk dan adat } \\
\text { - Sikap kritis yang menekankan } \\
\text { sifat holistik dalam aluk dan adat }\end{array}$ \\
\hline
\end{tabular}




\begin{tabular}{cllll}
\hline No & \multicolumn{1}{c}{$\begin{array}{c}\text { Aspek } \\
\text { Perbedaan }\end{array}$} & \multicolumn{1}{c}{ Rambu Solo' Dulu } & \multicolumn{1}{c}{ Rambu Solo' Kini } \\
\hline 5 & $\begin{array}{l}\text { Pilihan bentuk } \\
\text { upacara }\end{array}$ & $\begin{array}{l}\text { Mengacu pada status sosial dan } \\
\text { dilaksanakan secara tertutup. }\end{array}$ & $\begin{array}{l}\text { Mengacu pada status sosial dan } \\
\text { dilaksanakan secara terbuka. }\end{array}$ \\
\hline 6 & Hewan & $\begin{array}{l}\text { Sebagai penerang dan bekal bagi } \\
\text { orang yang meninggal. }\end{array}$ & $\begin{array}{l}\text { - Sebagai jamuan kepada tamu } \\
\text { - Sebagai penghormatan kepada } \\
\text { tokoh masyarakat } \\
\text { - Menunjukkan status sosial }\end{array}$ \\
\hline 7 & Arti kematian & $\begin{array}{l}\text { To makula' (belum sepenuhnya } \\
\text { mati) }\end{array}$ & Mati seutuhnya \\
\hline 8 & Pembiayaan & Sederhana & Cenderung pemborosan \\
\hline 9 & Waktu & Setelah pukul 12 siang & $\begin{array}{l}\text { Dapat dilaksanakan sebelum dan } \\
\text { setelah pukul 12 siang. }\end{array}$ \\
\hline
\end{tabular}

Penyesuaian yang ada dalam prosesi rambu solo' dikarenakan adanya pengaruh agama (Kristen) yang masuk dan berkembang di masyarakat suku Toraja. Akan tetapi, masuknya Kristenisasi di wilayah Toraja tidak lantas membuat berkurang atau hilangnya pelaksanaan prosesi rambu solo'. Yang terlihat adalah terjadinya proses sinkretisme dalam pelaksanaan prosesi rambu solo'. Prosesi ini yang sudah dijalankan secara turun temurun ini sudah menjadi tradisi bagi masyarakat suku Toraja. Tradisi ini telah mengakar dalam kehidupan masyarakat suku Toraja sehingga sulit untuk berubah atau menghilangkan. Hanya saja dalam pelaksanaannya pada masa kini, tejadi perpaduan dalam pelaksanaan rambu solo yang dulunya didasarkan atas kepercayaan masyarakat suku Toraja kepada Aluk Todolo' dan sekarang yang didasarkan pada ajaran agama (Kristen). Bentuk penyesuaian yang ada tidak mengasilkan suatu bentuk kebudayaan yang namun hanya terdapat beberapa perbedaan baik itu pada makna ataupun pelaksanaannya seperti yang disajikan pada tabel di atas.

Dalam aspek psikologis, pelaksanaan prosesi rambu solo' pada masyarakat suku Toraja didasarkan pada religiusitas yang dipegang dan dijalani oleh masyarakat suku Toraja. Religiusitas yang ada bukan hanya terlihat dari kepercayaan dahulu masyarakat suku Toraja (Aluk Todolo') atau kepercayaan pada masa sekarang ini (Agama Kristen), akan tetapi religiusitas juga melihat dari beberapa hal lainnya seperti pengetahuan, pengalaman, keyakinan, hingga konsekuensi yang didaat atau diperoleh dari pelaksanaan prosesi tersebut. Masuk dan berkembangnya agama (Kristen) pada masyarakat suku Toraja memberi 
pengaruh pada pelaksanaan prosesi rambu solo'. Akan tetapi Agama (Kristen) kemudian tidak menjadikan prosesi yang dahulunya didasarkan pada kepercayaan dahulu masyarakat suku Toraja menghilang. Religiusitas masyarakat suku Toraja dalam pelaksanaan rambu solo' masih juga tetap terlihat karena aspek-aspek dari religiusitas itu sendiri yang masih dipegang oleh masyarakat suku Toraja (Masuknya agama tidak menghilangkan pengetahuan, keyakinan, atau pengalaman sebelumnya masyarakat suku Toraja dalam menjalankan prosesi rambu solo') sampai dengan saat ini.

Rambu solo' sebagai prosesi kematian sangat sulit untuk dipahami oleh masarakat yang bukan berasal dari Wilayah Toraja. Dalam prosesi kematian ini tidak hanya suasana tangis dan duka saja yang telihat. Rambu solo' dapat dikatakan merupakan sebuah pesta atau perayaan bagi masyarakat suku Toraja dimana pelaksanaannya yang dapat berlangsung selama beberapa hari serta juga menghabiskan biaya yang lebih banyak dibandingkan prosesi atau ritual kematian pada kebudayaan-kebudayaan lain. Bahkan oleh Pemerintah Daerah setempat seperti yang dapat kita amati bersama menjadikan rambu solo' ini sebagai tempat wisata yang bersifat religi. Selain itu juga, seiring dengan masuk dan berkembangnya agama (Kristen) di wilayah Toraja, prosesi yang ada ini juga mengalami pergeseran baik itu dari segi makna maupun juga pelaksanaannya. Oleh karena itu peneliti ingin mengkaji mengenai prosesi ini secara psikologi. Adapun kajian psikologi yang dilakukan akan melihat prosesi ini dari sudut pandang atau teori religiusitas. Kajian yang dilakukan ini nantinya diharapkan dapat membantu menjelaskan rambu solo' tidak hanya sebagai prosesi pelestarian budaya saja melainkan juga makna psikologis khususnya religiusitas yang terdapat dalam pelaksanaan prosesi rambu solo' pada masyarakat suku Toraja.

\section{Metode}

Dalam penulisan ini, penulis melakukan kajian atau studi literatur dalam mengkaji aspek-aspek psikologis khususnya religiusitas dalam pelaksanaan prosesi rambu solo' pada masyarakat suku Toraja. Kajian atau studi literatur yang dilakukan yaitu dengan melakukan penelusuran pustaka yang terkait dengan topik 
penulisan, baik itu buku maupun jurnal hasil studi literatur dan penelitian sebelumnya.

\section{Hasil dan Pembahasan}

\section{Religiusitas}

Religiusitas diartikan sebagai suatu kumpulan tradisi kumulatif dimana semua pengalaman religius dari masa lampau dipadatkan dan diendapkan ke dalam seluruh sistem bentuk ekspresi tradisional yang bersifat kebudayaan dan lembaga. Sistem bentuk ekspresi tersebut meliputi seluruh simbol, upacara, peranan, dan cara hidup konkret khas yang senantiasa harus direfleksikan dan dihidupkan kembali agar semua itu tidak merosot menjadi fosil mati dan kulit kosong belaka. Religi atau sistem keagamaan merupakan sarana perwujudan "kepercayaan" yang bersifat tradisional dan terikat erat pada faktor-faktor historis, sosial, ekonomis, dan budaya ekstern. Tetapi religi dapat berfungsi juga sebagai sarana penyokong, penyalur, dan acuan bagi segala perasaan dan hubungan kita dengan yang transenden (Cremers \& Supratiknya, 1995).

Religiusitas merupakan sebuah komitmen yang maliputi hubungan agama atau keyakinan yang mana komitmen tersebut dapat diketahui melalui perilaku baik itu individu maupun kelompok dengan agama atau keyakinan iman mereka (Glock dan Stark, 1968). Religiusitas memiliki beberapa aspek atau dimensi lain menurut Glock dan Stark, antara lain belief dimension atau ideologi, religious Practice dimension atau praktik, experience dimension atau pengalaman, religious knowledge dimension atau pengetahuan, serta religious consequences dimension atau konsekuensi.

\section{Pelaksanaan Rambu Solo'}

Proses pelaksanaan prosesi rambu solo' dalam masyarakat suku Toraja terdiri dari beberapa tahapan. Terdapat 7 tahapan di dalam pelaksanaan prosesi rambu solo', antara lain sebagai berikut. 
Tahapan Pelaksanaan Rambu Solo'

\begin{tabular}{c}
\hline ma'palele \\
\hline ma'pasilagatedong \\
\hline ma'parokko alang \\
\hline mantarimatamu \\
mantunu \\
ma'kaburu
\end{tabular}

\section{Aspek Religiusitas Dalam Rambu Solo'}

Prosesi rambu solo' adalah prosesi untuk penguburan orang mati pada masyarakat suku Toraja. Prosesi yang sudah berlangsung secara turun temurun ini pada awalnya dilaksanakan pada kepercayaan masyarakat suku Toraja kepada Aluk Todolo'. Menurut kepercayaan masyarakat suku Toraja orang yang meninggal belum dikatakan meninggal seutuhnya sampai dengan dilakukannya prosesi tersebut. Sebagai bentuk dari kepercayaan tersebut, jenasah dari orang yang meninggal tersebut masih mendapat perlakuan yang sama seperti orang yang masih hidup. Hanya saja perlakuan yang didapat dalam bentuk perlakuan kepada orang yang sedang sakit atau sedang berada dalam kondisi tubuh yang lemah. Secara religiusitas, aspek yang mendasari kepercayaan tersebut yaitu belief atau ideologi. Pada aspek ini masyarakat suku Toraja berpegang teguh pada pandangan atau kepercayaan di atas serta mereka mengakui keparcayaan tersebut. Selain belief, bentuk pelakuan yang diberikan kepada orang yang telah meninggal lebih merujuk pada aspek experience atau pengalaman pada aspek religiusitas dari masyarakat suku Toraja. Pengalaman yang diperoleh dalam perlakuan tersebut diperoleh secara turun temurun.

Pelaksanaan prosesi rambu solo' terdiri dari beberapa tahapan yaitu dimulai dari ma' palele (memindahkan jenazah ke lokasi kegiatan), ma' pasilaga tedong 
(adu kerbau), ma' parokko alang (memindahkan jenazah dari tongkonan ke lumbung), ma' pasonglo' (pemindahan jenazah ke lakkian atau tempat persemayaman terakhir sebelum dikebumikan), mantarima tamu (menerima tamu) mantunu (pemotongan kerbau), dan ma' kaburu (acara penguburan). Tahapantahapan dalam pelaksanaan prosesi rambu solo' ini merupkan bagian dari religious practice atau praktik dalam aspek religiusitas, yang mana dalam aspek ini meliputi beberapa hal seperti pemujaan, ritual kepercayaan (agama), ketaatan, dan hal-hal lainnya sebagai bentuk komitmen terhadap agama atau kepercayaan yang dianut.

Penyesuaian atau sinkretisme yang ada pada rambu solo' kemudian menjadi dasar atau konsep dalam pelaksanaannya masa kini. Dasar keyakinan, prosesi pelaksanaan, dan tradisi yang disinskretis ini kemudian membentuk religious knowledge atau pengetahuan bagi masyarakat suku Toraja khususnya dalam melaksanakan prosesi tersebut pada masa kini.

Adapun sebagai bentuk religious consequences atau konsekuensi yang ada dari adanya sinkrestisme dari prosesi ini yaitu masyarakat suku Toraja menjadi lebih nyaman dalam melaksanakan prosesi ini. Masyarakat suku Toraja tetap melaksanakan prosesi rambu solo' yang merupakan tradisi kebudayaan turun temurun yang didasarkan pada Aluk todolo' namun juga tetap mendasari niai-nilai atau ajar agama (Kristen) sebagai dasar dalam pelaksanaannya.

\section{Kesimpulan dan Saran}

\section{Kesimpulan}

Rambu solo' sebagai prosesi untuk menguburkan orang yang telah mati pada masyarakat suku Toraja merupakan sebuah tradisi yang tetap terus dijalankan sampai dengan saat ini. Akan tetapi, dalam pelaksanaannya terjadi sinkretisme atau penyesuaian antara kepercayaan dahulu masyarakat suku Toraja (Aluk Todolo') dengan agama (Kristen) yang telah masuk dan menyebar di wilayah Toraja sebagai dasar dalam pelaksanaan rambu solo'. Proses penyesuaian yang ada tidak menjadikan berubahnya secara keseluruhan atau menghilangnya prosesi ini dikarenakan nilai-nilai religiusitas yang dimiliki oleh masyarakat suku 
Toraja. Religiusitas yang ada bukan cuma dilihat dari agama yang saat ini dianut oleh masyarakat suku Toraja, melainkan keyakinan-keyakinan atau kepercyaankepercayaan yang didapat atau diperoleh secara turun-temurun (tradisi) yang telah mengakar dalam kehidupan masyarakat suku Toraja. Rambu solo' adalah salah satu bentuk religiusitas yang ada dalam kehidupan karena prosesi ini didasari tidak hanya pada nilai-nilai atau kepercayaan dalam tradisi yang telah ada sebelumnya dan diwariskan secara turun temurun, namun juga adanya nilai-nilai agama khususnya kristiani yang kemudian kedua hal ini dijadikan dasar dalam pelaksanaan prosesi yang ada pada saat ini.

\section{Saran}

Tulisan ini merupakan hasil kajian studi literatur mengenai aspek psikologis khususnya religiusitas dalam pelaksanaan prosesi rambu solo'. Peneliti selanjutnya disarankan untuk melakukan eksplorasi lapangan untuk dapat melihat dan mengetahui secara langsung mengenai prosesi ini sebagai bentuk konfirmasi atas temuan dalam tulisan ini lalu kemudian dapat melakukan kajian mengenai aspek-aspek lainnya dalam pelaksanaan prosesi rambu solo’.

Untuk Pemerintah dan Tokoh Adat setempat diharapkan pula agar dapat melibatkan diri dalam pelaksanaan prosesi ini yaitudengan melakukan kontrol dan pengawasan dalam pelaksanaan prosesi ini serta membentuk regulasi yang tepat agar pelaksanaan prosesi ini dapat terlaksana sesuai dengan nilai-nilai yang dipegang teguh dan diwariskan dari generasi sebelumnya hingga generasi sekarang serta pula agar tidak terjadi penyelewengan dari pelaksanaan prosesi rambu solo' pada masyarakat suku Toraja.

\section{DAFTAR PUSTAKA}

Cremers, A \& Supratiknya (1995). Tahap tahap perkembangan kepercayaan menurut James W. Fowler: Sebuah gagasan baru dalam psikologi agama. Yogyakarta: Kanisius.

Glock, C.Y. \& Stark, R. (1968). American Piety: The nature of religious commitment. Berkeley: University of California. 
Guntara, F. Fatchan, A. \& Ruja, I. N. (2016). Kajian sosial budaya rambu solo’ dalam pembentukkan karakter peserta didik. Jurnal Pendidikan, Teori, Penelitian, dan Pengembangan (1) 2, 154-158.

Hasbi, Sukimi, \& Mutalib. (2016). Upacara rambu solo’ dulu dan kini di Makale Utara Tana Toraja. e-Bangi, Journal of Social Sciences and Humanities, Special Issue (1), 121-129.

Mangera, E. \& Arrang, J. T. (2018). Bentuk komunikasi fatis dalam masyarakat Toraja pada upacara rambu solo' di kecamatan Gandang Batu Sillanan Kabupaten Tana Toraja. Jurnal KIP, (7) 1, 9-17.

Mangopang, J. Widiarto, T. \& Sunardi. (2018). Tedong sebagai syarat dalam upacara rambu solo' di Kecamatan Makale Kabupaten Tana Toraja. Jurnal KIP, (7) 3, 18-24.

Marwing, A. (2011). Problem psikologis dan strategi coping pelaku upacara kematian rambu solo' di Toraja (Studi fenomenologi pada tana' bulaan). Psikoislamika, Jurnal Psikologi Islam (JPI), 8 (2), 209-230.

Wahyuningsih, D. (2018). Representasi ritual upacara kematian adat suku Toraja dalam dokumenter Indonesia Bagus Net TV episode Toraja. Ejournal Ilmu Komunikasi, 6 (1), 68-82. 